ANALYSIS

\title{
Rule making in community forestry institutions: The difference women make
}

\author{
Bina Agarwal * \\ Institute of Economic Growth, University of Delhi, Delhi 110007 India
}

\section{A R T I C L E I N F O}

\section{Article history:}

Received 2 January 2009

Received in revised form 1 February 2009

Accepted 24 February 2009

Available online 7 April 2009

\section{Keywords:}

Community forestry institutions

Rule making

Gender composition

South Asia

\begin{abstract}
A B S T R A C T
Forest use rules determine what products are extracted from community governed forests, in what quantity, by what methods, and by whom. The nature of rules and the process by which they are formulated (e.g. who participates in formulating them) can impinge critically on institutional sustainability (given their potential impact on the commitment and incentive to protect), and on equity and conservation outcomes. This is well recognized in the substantial literature on institutions governing common pool resources (CPRs). It is also well recognized, although in relation to other types of institutions, such as legislatures and village councils, that there can be notable differences in women's and men's policy priorities. Yet there is surprisingly little existing work on, or statistical testing of, potential gender differences in rule making in institutions managing natural resources such as forests. This paper, based on the author's primary data for India and Nepal, seeks to fill this conceptual and empirical gap. It examines why we might expect women to favour different rules from men, and statistically tests whether the gender composition of the executive committees (ECs)-the main decision-making bodies of community forestry institutions (CFIs) in South Asia-makes a difference to the strictness of forest use rules. This is analyzed both by specifying a strictness index which aggregates rules across products and by examining rules for selected products, and both for all sample districts together and for each district separately. Gender is found to make a significant difference to the rules specified but not always in the expected direction. Given their substantial and daily dependence on local forests, especially for firewood and fodder, rural women may normally be expected to veer toward lenient rules of extraction. In fact, groups with more EC women and especially with all-women ECs tend to make stricter rules than other groups in most of the sample districts, except one district where they tend to make less strict rules. Greater strictness is attributable especially to the resource constraint faced by all-women groups (ie. CFIs with allwomen ECs) which receive smaller and more degraded forests than groups with men. Less strict rules among CFIs in the exceptional district are attributable especially to the disproportionate presence of landless women on their ECs. In other words, not simply women's presence in rule making but also their economic class can matter. Strictness also varies by type of product, forest and population characteristics, the EC's average age and dominant caste, and monitoring constraints. The potential implications for equity, institutional sustainability and forest conservation are also discussed.
\end{abstract}

(c) 2009 Elsevier B.V. All rights reserved.

\section{Introduction}

Male members of the forest committee have difficulties in implementing the rules. Women could discuss these problems with the men. Perhaps more 'mid-way' rules would be, in the long run, more effective... more viable (Nepalese village women cited in Britt, 1993, 148)

The formulation of rules that define what is 'required, prohibited, or permitted' is widely recognized as central to the functioning of institutions governing common pool resources (CPRs) in the burgeon-

\footnotetext{
* Fax: +911127667410.

E-mail address: bina_india@yahoo.com.
}

ing literature on the subject. ${ }^{1}$ Indeed, Ostrom (1990) identifies rule making as one of the central design principles for building enduring institutions for CPR governance. But are the rules likely to differ depending on who frames them? In particular, are men and women likely to frame different rules of forest use due to, say, differences in responsibilities and priorities? If so, the gender composition of the rule making body could significantly affect institutional functioning. Research relating to other types of institutions such as legislatures and village councils does point to notable differences in men's and women's policy priorities. A substantial body of work on legislators in democratic regimes, for instance, finds that women give significantly

\footnotetext{
${ }^{1}$ The phrase in quotation marks is taken from Ostrom et al. (1997, 38). On the importance of rules see among others, Ostrom (1990), various articles in Ostrom et al. (1997), Baland and Platteau (1996), Mckean (1986), Wade (1988), Agrawal (1997), Arnold and Campbell (1986), Bardhan (2006), and references therein.
} 
greater priority than their male colleagues to laws and policies that promote women's equality and empowerment, or that improve family welfare through health, education, childcare, housing and other human services. ${ }^{2}$ Similarly, emerging work shows that women heads of local councils in India differ from male heads in the public goods they favour: women are found more likely to prioritize issues seen as falling largely in women's domain, such as drinking water and sanitation (e.g., Chattopadhyay and Duflo, 2004; Gandhi and Shah, 1991; Vijaylakshmi, 2004).

There is, however, surprisingly little existing research on whether women's presence in institutions managing natural resources, such as forests, is likely to make a difference to the decisions made, in particular the rules formulated for forest use. The limited existing discussion is largely inferential, with virtually no theorizing on why we might expect gender differences in rule making, or statistical testing (either for South Asia or elsewhere) of the actual impact of women's participation in rule formulation. This paper seeks to fill this conceptual and empirical gap. It examines whether the gender composition of the executive committees (ECs)-the principal decision-making bodies of community forestry institutions (CFIs) in South $\mathrm{Asia}^{3}$-makes a difference to forest use rules, especially their extent of strictness. Do groups with more women in their ECs make less or more strict rules? Does a larger proportion of poor landless women in the EC make a particular difference? Do all-women groups make rules of different strictness than, say, mixed-gender groups?

These questions are addressed on the basis of primary data for Gujarat (India) and Nepal, collected by me mainly during 2000-2001 from communities governing forest land, transferred to them by the government to protect and manage. Details about these institutions and fieldsites are given further below. Although the analysis is focused on South Asia, the framework, methodology and issues discussed would have wider geographic relevance.

\section{Why forest use rules matter}

The most important set of rules made by CFIs are those relating to forest use involving the extraction and distribution of forest products (also termed by some as 'allocation rules': Agrawal, 1997). Penalties for violating these rules could be seen as a secondary set of 'rules', but effectively penalties are a means of ensuring compliance to forest use rules, and not all CFIs specify detailed penalties. ${ }^{4}$ I have therefore focused here on forest use rules. These rules determine what products are extracted and distributed from the protected area, in what quantity and frequency, by what means, when, and by whom. The rules matter for their potential impact on institutional sustainability, on the equity of benefit-sharing, and on forest conservation (which one might term the efficiency effect of governance). ${ }^{5}$

Consider firewood extraction. Potentially the rules can range from a complete ban on collection to varying degrees of permissible extraction. For instance, the collection of fallen twigs may be allowed, but taking drywood from the trees may be banned; or taking drywood may be allowed if done by hand, but not with an axe. Such extraction may be permitted throughout the year or only for a few days annually; and anyone may be permitted to enter the forest in this period or only

\footnotetext{
2 See, e.g. Berkman and O'Connor (1993), Carroll (2001), Darcy et al. (1994), HighPippert and Comer (1998), Norris and Lovenduski (1995), Saint-Germain (1989), Swers (2001), Thomas (1994), Thomas and Welch (2001), Vallance (1988), and Wängnerud (2000)

${ }^{3}$ I use the term CFI to connote all types of community forestry groups in South Asia, but in particular those that fall under India's Joint Forest Management Programme and Nepal's community forestry programme.

${ }^{4}$ Monitoring for rule compliance, occasional tree planting, clearing undergrowth, and so on, that CFIs undertake are essentially 'activities' rather than rules.

5 The term 'efficiency' is not used here to imply the conventional economics formulation of Pareto efficiency, but in a more general sense of the ability to produce a desired product, achieve institutional goals, etc., with a minimum of effort, expense, or waste.
}

one or two persons from member households. Other forest products may similarly be subject to varying restrictions, leading to numerous rule permutations.

On such rules would depend the benefits derived by the local population from forest protection. This impinges, first, on the incentive and commitment to protect the forest, since protection involves bearing costs and people expect appropriate benefits. These costs could either be direct, such as contributing to patrolling time or paying for a guard, or indirect, such as foregoing resource use by complying with the rules prescribed. ${ }^{6}$

Second, rules can have differential consequences by class and gender. Strict rules (a complete ban on extraction, for instance) affect the poorest households and women in general more adversely, given their substantial dependence on forests for subsistence. Women may end up spending more time and energy in firewood collection, economizing on fuel use, or using inferior and more health-damaging fuels as substitutes (Agarwal, 2001). Poor, landless women would be the most adversely affected. In other words, the equity and welfare outcomes of CFI formation could depend on the strictness of forest use rules.

Third, rules can affect forest condition but in rather complicated ways. Strict rules, if effectively implemented, can benefit regeneration, but overly strict rules are difficult to enforce and could increase violations and conflicts, with potentially damaging effects on forest condition. South Asia's colonial history is replete with examples of forest fires caused by resentful villagers whose customary collection rights were curtailed (Bhattacharya, 1992; Sivaramakrishnan, 1999). In contrast, moderate rules may prove beneficial for conservation by encouraging cooperation. Regeneration could also improve with moderate rules because some forms of extraction can enhance biomass growth. Similarly, clearing forest undergrowth can reduce the risk of fire. Forest use rules thus need to be neither so lenient as to degrade the resource further (by over-extraction), nor so strict as to undermine the incentive to protect and the ecological benefits of selected extraction. The appropriate level of strictness would be that which is adapted to local conditions.

The process of rule making-bottom-up or top-down-can also affect their impact. Even those who are adversely affected by the strict rules may accept them if they are involved in rulemaking. Among water users groups, for example, Bardhan (2006) found a positive association between rule compliance and participation in rule formulation. In other words, the very involvement in rule making (through consultation, representation or direct voice) of those most affected by the rules and who are expected to follow them could prove important for institutional sustainability. The EC's gender composition can help capture the impact of women's presence both on the rules made and (implicitly) on the process by which they are made.

\section{Context and data}

My analysis is based on CFIs in India and Nepal which manage government forests given over to local communities/user groups to protect and govern. Most groups, whether catalyzed by communities, NGOs or forest officials, are registered under the Joint Forest Management (JFM) programme launched in India in 1990 and a somewhat similar community forestry initiative in Nepal in $1993 .{ }^{7} \mathrm{By}$ the early 2000s, India had around 84,000 JFM groups involving 8.4 million households and $22.5 \%$ of its forest land, and Nepal had around 10,000 forest user groups involving about 1 million

\footnotetext{
${ }^{6}$ Of course in some contexts people can transcend material incentives and come to view conservation as having intrinsic worth (Agrawal, 2005).

7 There is a vast body of work on community forestry in India and Nepal-its origins, functioning and performance-which cannot be discussed here, but see among others, Agarwal (2001, 2006, forthcoming), Sundar et al. (2001), Poffenberger and McGean (1996), Hobley (1996), Springate-Baginski and Blaikie (2007), and references therein.
} 
households and $11.4 \%$ of its forest land. ${ }^{8}$ Forest land in both India and Nepal is almost entirely government owned. Typically, most states in India (including Gujarat, where this study was done) only transfer degraded forest land to village communities to manage. In Nepal, however, better forests can also be so transferred.

Organizationally, in both India and Nepal, the CFIs have a two-tier structure, consisting of a general body (GB) with members drawn from the whole village or community of users and an executive committee of around 9-15 members. The EC in interaction with the GB (and sometimes with the forest department), defines the rules for forest use and benefit-sharing. In India, CFIs have rights to extract non-timber products and, in conjunction with the forest department, to a share of any mature timber harvested. In Nepal, legally the CFIs are entitled to the full share of benefits, including timber for personal use, but in practice the forest department restricts timber cutting and retains the right to define 'sustainable harvest levels' (Ojha and Timsina, 2008, 216).

My sample consists of 65 CFIs located in three districts of Gujarat in west India and 70 CFIs located in three districts of Nepal in the middle hills. The Gujarat districts are Narmada/Bharuch, ${ }^{9}$ Panchmahals and Sabarkantha. Each has an important NGO working on natural resources management, but all three have broadly similar aims. The main reason for choosing Gujarat was that these district-level NGOs had information on the gender composition of CFIs. This information was essential for sample selection. No state in India collects comprehensive information of this kind. Nepal does have such information and this served as the basis of district identification for the study (for details, see Agarwal, forthcoming). Ecologically the Gujarat districts fall in a semi-arid zone, with dry deciduous forests. The sample population is poor and predominantly tribal.

The Nepal districts are Baglung, Parbat and Gorkha, with a small spillover of the sample into Dhading district when replacement CFIs were needed for Gorkha. ${ }^{10}$ All the districts fall in Nepal's middle hills, a sub-tropical zone with mostly deciduous forests, a significant ethnic population and substantial poverty. The identified districts, however, have relatively low levels of complete landlessness (6-13\% of the households here are landless compared with $21 \%$ in the Nepal hills as a whole: GoN, 2001).

The CFIs were selected through stratified random sampling from the population of CFIs in each of the identified districts in Gujarat. In Nepal, Baglung and Parbat districts were clubbed for sampling due to a limited universe of CFIs with a given gender composition in each, and Gorkha was sampled separately. ${ }^{11}$ The main criterion for sample selection was the EC's gender composition stratified into three mutually exclusive categories: all-women ECs, ECs with $\leq 2$ EC women and those with $>2$ women (but not all-women). The twowoman marker stemmed from the requirement in Gujarat (as in several other Indian states) that there should be least two women on the EC. Although in practice many ECs have less than two women and some have more, this is a relevant criterion since including only two women is a nominal way of following the rule, and including more than two women is a departure from the minimum requirement. Gujarat has very few all-women ECs. In Nepal there are 'guidelines' recommending women's inclusion in ECs, but no mandate. For comparability with Gujarat, however, I used the two-woman marker

\footnotetext{
${ }^{8}$ For India see Bahuguna (2004). Nepal's figures are computed from national-level data available in the 'FUG Database' and periodically updated (CPFD, 2000).

${ }^{9}$ Earlier Narmada district was a part of Bharuch. The sample CFIs fall mainly in Narmada.

${ }^{10}$ Four of Gorkha's originally sampled CFIs became inaccessible due to the Maoist insurgency and had to be replaced by CFIs with the same gender composition from adjacent Dhading district.

${ }^{11}$ Baglung and Parbat are contiguous with similar ecological and social profiles. Each had insufficient all-women CFIs and were therefore clubbed for sample selection. Gorkha, with a fair number of all-women CFIs, was treated as a separate unit.
}

also for selecting Nepal's sample, in addition to the all-women ECs of which there are a fair number here.

In Gujarat $48 \%$ of the sample CFIs have ECs with $\leq 2$ women and $52 \%$ have $>2$ women. There are three all-women and five all-men ECs. In Nepal, $39 \%$ of the CFIs have ECs with all-women, $28 \%$ have $\leq 2$ women (including 5 all-male ECs) and 33\% have $>2$ women. These distributions do not represent the universe, since the sample was purposively selected, given that my interest was in assessing the impact of women's proportional strength on rule making and not in why some ECs had few women and others many. Nevertheless, I probed what factors underlay variations in the EC's gender composition and found a mix of context-specific, non-systematic factors which varied from village to village (as detailed in Agarwal, forthcoming). For instance, some CFIs with high female presence in the EC had a prior history of women's group activity unrelated to forestry; others had forests with a high availability of products that women collect; yet others had a gender-sensitive NGO staff member or village leader who had promoted women's inclusion, driven by considerations of gender justice and women's empowerment.

Both quantitative and qualitative information was obtained on the characteristics of the CFI (especially its EC), the forest, the population and the village, using several types and levels of questionnaires. Focused group discussions were held with EC members and separately with male and female villagers, as well as individual interviews with key informants. Where possible, information was double-checked with any written records kept by the CFI. For data on land ownership and selected population characteristics a separate questionnaire was fielded for each Gujarat village and one tole for each Nepal CFI (a tole is between a hamlet and a village in size). In addition, in Nepal, a forest officer provided valuable data on the CFI and the forest from the forest department's files. In Gujarat, each CFI is linked with a specific village. In Nepal, members of one CFI can come from several toles, and a single forest can have more than one CFI protecting non-overlapping parts. Here no clear set of 'village' characteristics can be identified. The Gujarat and Nepal samples therefore cannot be clubbed together for analysis without losing information available for Gujarat but not for Nepal. They have thus been analyzed separately.

\section{Diversity of forest use rules}

Forest use rule making involves various types of decisions, such as whether to extract, what to extract, how much to extract, and how to distribute what is extracted. Embedded herein are not only specifications for regulated forest use but also concern for conservation (e.g. whether to allow unrestricted grass cutting or to restrict extraction to specified plots by rotation). Affecting these decisions is a complex interplay of ecological conditions and negotiations/interactions between different parties (such as the EC members, other villagers, and external actors) with varying interests. Ecologically, for instance, the regeneration of a highly degraded forest may require banning the unregulated entry of all humans and animals and forbidding all wood extraction. However, with low or non-existent tree cover and a ban on grazing, a good harvest of grass can be reaped, especially postmonsoon. Similarly, woody biomass revives if the rootstock is intact, but haphazardly. Some shoots need pruning a few years into protection, and the cut wood can be distributed. Also trees produce a flow of twigs and fallen branches. Seasonal non-wood forest products (NWFPs) may revive as well. As the forest ages there is less risk of young shoots being trampled. Grazing can then be allowed. As one Gujarat villager explained to me: 'In the beginning there was a rule that animals should not be allowed to graze in the protected area. This was decided because there was a danger that they will eat the saplings. Now the rules have changed as the plants have grown and they are under no danger.'

Potentially therefore, with protection, a degraded resource can yield seasonal benefits to the community in the form of grass fodder 
Table 1

Gujarat: forest use rules after protection began (\% CFIs).

\begin{tabular}{|c|c|c|c|c|}
\hline $\begin{array}{l}\text { Products extracted, strictness rules } \\
\text { and weights (in brackets) }\end{array}$ & $\begin{array}{l}\text { Open } \\
\text { always } \\
(1)\end{array}$ & $\begin{array}{l}\text { Open } \\
\text { occasionally } \\
(2.5)\end{array}$ & $\begin{array}{l}\text { Partial ban or } \\
\text { given on request }{ }^{\text {a }} \\
(2.75)\end{array}$ & $\begin{array}{l}\text { Full } \\
\text { ban } \\
(3)\end{array}$ \\
\hline \multicolumn{5}{|l|}{$\%$ CFIs } \\
\hline \multicolumn{5}{|l|}{$\leq 2$ EC women CFIs $(N=31)$} \\
\hline Fallen twigs collection & 64.5 & 29.0 & 0.0 & 6.4 \\
\hline Dry wood cutting & 29.0 & 29.0 & 3.2 & 38.7 \\
\hline Grass fodder cutting & 48.4 & 35.5 & 3.2 & 12.9 \\
\hline Grazing & 32.2 & 0.0 & 45.2 & 22.6 \\
\hline Timber species for firewood & 0.0 & 0.0 & 0.0 & 100.0 \\
\hline $\begin{array}{l}\text { Timber poles for house } \\
\text { building, etc. }\end{array}$ & 0.0 & 3.2 & 9.7 & 87.1 \\
\hline \multicolumn{5}{|l|}{$>2$ EC women CFIs $(N=34)$} \\
\hline Fallen twigs collection & 52.9 & 17.6 & 0.0 & 29.4 \\
\hline Dry wood cutting & 23.5 & 29.4 & 2.9 & 44.1 \\
\hline Grass fodder cutting & 50.0 & 44.1 & 2.9 & 2.9 \\
\hline Grazing & 47.1 & 2.9 & 23.5 & 26.5 \\
\hline Timber species for firewood & 0.0 & 0.0 & 2.9 & 97.1 \\
\hline $\begin{array}{l}\text { Timber poles for house } \\
\text { building, etc. }\end{array}$ & 0.0 & 0.0 & 11.8 & 88.2 \\
\hline \multicolumn{5}{|l|}{ All CFIs $(N=65)$} \\
\hline Fallen twigs collection & 58.5 & 23.1 & 0.0 & 18.5 \\
\hline Dry wood cutting & 26.2 & 29.2 & 3.1 & 41.5 \\
\hline Grass fodder cutting & 49.2 & 40.0 & 3.1 & 7.7 \\
\hline Grazing & 40.0 & 1.5 & 33.8 & 24.6 \\
\hline Timber species for firewood & 0.0 & 0.0 & 1.5 & 98.5 \\
\hline $\begin{array}{l}\text { Timber poles for house } \\
\text { building, etc. }\end{array}$ & 0.0 & 1.5 & 10.8 & 87.7 \\
\hline
\end{tabular}

Source: author's 2000-2001 survey.

$N=$ number of CFIs.

a Given on request for special need or natural disaster.

and drywood on a fairly regular basis and, depending on local biodiversity, other products as well. In addition, it can yield timber when mature. In contrast, if the forest already has good tree cover when handed over to the community, there may be less grass and more of other products. Whether or not these potential benefits are reaped, however, depends on the rules. Here there is scope for negotiation and exercising influence by different segments of the population as well as other interested parties, such as the forest department.

The emergent rules are likely to reflect both processes-ecological condition and negotiation/influence-leading to considerable diversity by product, CFI and region. In my study, information on rules relates to those formulated and practiced around the time when CFIs began formal protection (although in Gujarat some CFIs had begun informal protection earlier). ${ }^{12}$ Broadly, I found five levels of strictness in rules, although not all applied to each product (see Tables 1 and 2): complete ban on collection; partial ban (e.g. ban for certain seasons, or on grazing by certain animals, such as goats); given on special request in case of special need; ${ }^{13}$ occasional opening for a specified period; and open always. 'Open always' does not mean 'open access'-it means open for the protecting village but not for other villages.

In Gujarat, the most lenient rules-'open always'-are for seasonal NWFPs and fallen twigs, and the strictest rules apply to timber cutting which is banned in all the CFIs, although a few give out some 'on request' (sometimes required in writing) for a special need. Fodder cutting and grazing are subject to rules of moderate strictness (Table 1). Also in parts of Gujarat, as in Panchmahals, CFIs distinguish between timber species and firewood species, such as ganda babul,

\footnotetext{
12 In Nepal, information provided by the EC could be cross-checked in many cases with written records dating to the time of CFI formulation. Gujarat lacked such records but follow-up questions about rule changes provided some cross-checking of the original rules.

13 Partial ban and given on request are consolidated in Tables 1 and 2 .
}

which has little commercial value but substantial fuel value. This can be cut by women on forest opening days.

Almost all the sample Gujarat forests were highly degraded when informal protection began and most villagers began by banning all collection. Technically some CFIs continued to allow the collection of fallen twigs and NWFPs, but often there was little available of either. In some areas, such bans substantially increased women's firewood collection time and distance travelled (Sarin 1998; Agarwal, 2001). When neighbours started protecting, these options too were foreclosed, and most women switched in part to inferior fuels-cropwaste, twigs, even straw. Women's complaints about strict closure were frequent and bitter.

Protection, however, allowed fodder and wood to regenerate. In an economy where cattle plays an important role, many CFIs instituted formal rules for fodder harvesting in both Narmada/Bharuch and Sabarkantha, but not in Panchmahals where grass was sparse, and the land was covered largely with bushes. In terms of trees, the hardy teak common in the area readily revived where the rootstock was intact. The initial pruning provided cut wood which was distributed among the villagers, but since cutting was done at intervals of several years, it did rather little to alleviate chronic fuel shortages. Over time, some CFIs, in response to women's complaints began opening the forest for a few days annually, but many kept their bans despite biomass availability. In the Narmada/Bharuch villages, for instance, all the CFIs continue to ban greenwood cutting and $88 \%$ ban even drywood collection.

In Nepal, since the forests transferred to communities were on average in better condition and more biodiverse than in Gujarat, the CFIs could, if they wanted, allow more extraction. In practice, the rules are stricter on many counts (Table 2). Drywood is cut periodically, but infrequently, and less than half the CFIs allow twig collection on an open basis. Hence in Nepal also, women in most CFIs complain about firewood shortages. Timber (typically 'small timber' of $<3 \mathrm{ft}$ girth), however, is more often given out on request in Nepal (some $60 \%$ of CFIs allow this) than in Gujarat.

Table 2

Nepal: forest use rules after protection began (\% CFIs).

\begin{tabular}{|c|c|c|c|c|}
\hline $\begin{array}{l}\text { Products extracted, strictness } \\
\text { rules and weights (in brackets) }\end{array}$ & $\begin{array}{l}\text { Open } \\
\text { always (1) }\end{array}$ & $\begin{array}{l}\text { Open } \\
\text { occasionally } \\
(2.5)\end{array}$ & $\begin{array}{l}\text { Partial ban or given } \\
\text { on request }^{\mathrm{a}}(2.75)\end{array}$ & $\begin{array}{l}\text { Full } \\
\text { ban } \\
(3)\end{array}$ \\
\hline \multicolumn{5}{|l|}{$\%$ CFIs } \\
\hline \multicolumn{5}{|l|}{ All-women EC CFIs $(N=27)$} \\
\hline Twigs collection & 44.4 & 44.4 & 0.0 & 11.1 \\
\hline Drywood cutting & 0.0 & 96.3 & 0.0 & 3.7 \\
\hline Tree fodder plucking & 0.0 & 33.3 & 3.7 & 63.0 \\
\hline Grass fodder cutting & 40.7 & 55.6 & 3.7 & 0.0 \\
\hline Grazing & 22.2 & 3.7 & 14.8 & 59.3 \\
\hline Timber cutting & 0.0 & 0.0 & 51.8 & 48.2 \\
\hline Leaf litter collection & 44.4 & 33.3 & 0.0 & 22.2 \\
\hline \multicolumn{5}{|l|}{ Other CFIs $(N=43)$} \\
\hline Twigs collection & 46.5 & 39.5 & 7.0 & 7.0 \\
\hline Drywood cutting & 2.3 & 86.0 & 4.7 & 7.0 \\
\hline Tree fodder plucking & 0.0 & 30.2 & 11.6 & 58.1 \\
\hline Grass fodder cutting & 41.9 & 48.8 & 2.3 & 7.0 \\
\hline Grazing & 30.2 & 7.0 & 14.0 & 48.8 \\
\hline Timber cutting & 0.0 & 0.0 & 69.8 & 30.2 \\
\hline Leaf litter collection & 37.2 & 39.5 & 4.6 & 18.6 \\
\hline \multicolumn{5}{|l|}{ All CFIs $(N=70)$} \\
\hline Twigs collection & 45.7 & 41.4 & 4.3 & 8.6 \\
\hline Drywood cutting & 1.4 & 90.0 & 2.8 & 5.7 \\
\hline Tree fodder plucking & 0.0 & 31.4 & 8.5 & 60.0 \\
\hline Grass fodder cutting & 41.4 & 51.4 & 2.9 & 4.3 \\
\hline Grazing & 27.1 & 5.7 & 14.3 & 52.9 \\
\hline Timber cutting & 0.0 & 0.0 & 62.9 & 37.1 \\
\hline Leaf litter collection & 40.0 & 37.1 & 2.9 & 20.0 \\
\hline
\end{tabular}

Source: author's 2000-2001 survey.

$N=$ number of CFIs.

a Given on request for special need or natural disaster. 
In both regions, fodder rules are the most fine tuned. They vary not just in whether fodder can be extracted, but also how it is to be extracted and distributed. In some districts, such as Narmada/ Bharuch and Baglung/Parbat, most CFIs have formal procedures for cutting and distributing fodder. The forest is opened seasonally for a few days, and one or two persons per member household are allowed in. Some CFIs specify equitable distribution methods, such as giving equal bundles to all member households that participate in cutting fodder (Table 3: see CFIs 1and 2 in Gujarat). Other CFIs disregard equity altogether, treating fodder like a market good and auctioning it: in CFI 1 in Nepal, for instance, the grass area is divided into three plots and each plot is auctioned to a single highest bidder. The remaining households have to buy fodder from the successful bidders at the price the latter set. In some other CFIs, a few rich bidders get all the grass and the money goes into a community fund. Women usually have little say in the use of funds, which are used for giving loans to members, community development, paying the forest guard, and so on, and not for relieving fuel and fodder shortages. This also means that many who have been protecting the forest get nothing or have to buy grass at high prices. The bitterest complaints about forest use rules come from women where auctioning is practiced. Here are some samples from my discussion in 1998 with women in Ghusra village, Dang district, Nepal:

The community forest belongs to the men. We own nothing. Even the grass is auctioned off. Whoever pays more gets it.

The money obtained from grass and firewood is kept by them in their fund. We have not seen one penny of it. We buy grass, which is auctioned by bundles.

Successful bidders can also cause damage by careless and excessive extraction, as found by Agrawal (1997) in Kumaon (India), where too such auctions were deeply resented. Between the two extremesequal bundles and auctions-are a complex array of distribution systems, with varying equity effects.

The extraction and distribution of firewood (as drywood and greenwood), unlike fodder, is seldom based on a regularized system and the contrast between the two products is striking. In the Gujarat sample, virtually none of the CFIs have formal procedures for cutting and distributing firewood. People can simply collect drywood when the forest is opened, except when cleaning/pruning/thinning is done once every few years for enhancing tree growth, by lopping off uneven branches and clearing the undergrowth. The cut wood is usually distributed equally among the participating households. The contrast with fodder is starkest in Narmada/Bharuch where most CFIs have banned drywood cutting but carefully supervise fodder extraction (Table 4). In Nepal, although most CFIs do extract firewood periodically through formal procedures, this is again part of the standard silviculture practice of pruning and clearing; and unlike for fodder it is not a system instituted for the members' benefit, although women may benefit by default from the cut wood that is distributed.

Why does firewood get less attention than fodder? Several factors appear to impinge on this-the importance of animals in the local economy, the financial cost of procuring fodder if not obtained from the forest, and gender bias. In Nepal draught animals are needed for hill cultivation, and in several Gujarat sites there is a flourishing milk economy. Hence men share with women a significant interest in fodder, while firewood is predominantly in women's domain. Also if the family cannot collect fodder freely it has to buy some, or sell animals. Many households report a fall in their animal stock and an increase in fodder purchase, since protection began. Formal extraction and distribution of forest products require careful supervision. Typically men supervise. Given the potential costs linked with fodder shortages, male CFI members think it worthwhile to put in the time and effort for fodder extraction but not for firewood, which is seldom purchased, and the costs of shortages (extended collection and cooking time, adverse health effects) are non-monetary, less visible and borne mainly by women and children.

All products are thus subject to some regulation, but CFIs differ in complex ways in the strictness of their rules. Our interest is in examining how the EC's gender composition affects this strictness, after controlling for other factors.

\section{What affects strictness in rules?}

Given the complexity and range of forest use rules, we need some kind of aggregation to compare rules across CFIs. For this purpose, I computed an aggregated strictness index. Some additional analysis was done product-wise.

Table 3

Grass collection rules-illustrative examples.

\begin{tabular}{|c|c|c|c|}
\hline State/country/CFI & Days open & No. of persons allowed entry & Method \\
\hline \multicolumn{4}{|l|}{ Gujarat, India } \\
\hline CFI 1 (Narmada) & A few days per year & $\begin{array}{l}\text { Maximum } 2 \text { persons per } \\
\text { member household, usually } \\
\text { women go }\end{array}$ & $\begin{array}{l}\text { The cut grass is tied into bundles, } 10 \% \text { of which are given to the EC and the rest is distributed } \\
\text { equally among the participating households. For distribution, the bundles are placed in equal } \\
\text { piles and each pile is given a number. Each member picks a number at random and takes the } \\
\text { relevant pile. They have followed this rule for } 9 \text { years. }\end{array}$ \\
\hline CFI 2 (Sabarkantha) & $\begin{array}{l}10 \text { days per year after } \\
\text { discussion in meeting }\end{array}$ & $\begin{array}{l}1 \text { person per member } \\
\text { household for cutting }\end{array}$ & $\begin{array}{l}\text { Each participant is given a token. The forest is divided into } 4 \text { plots and } 10 \text { people supervise } \\
\text { each plot. Each participating household is assigned to one of the } 4 \text { groups, and each group is } \\
\text { sent to cut one plot. About } 300 \text { out of } 400 \text { village households participate. }\end{array}$ \\
\hline \multicolumn{4}{|l|}{ Nepal } \\
\hline CFI 1 (Baglung) & $\begin{array}{l}\text { Once a year after } \\
\text { the monsoon }\end{array}$ & & $\begin{array}{l}\text { A GB meeting is called and the names of those who want grass are noted down. } \\
\text { The grassy area is divided into three plots and each plot is auctioned to one bidder. } \\
\text { The remaining households have to buy what they need from the bidders. This reduces } \\
\text { the EC's supervision cost since the successful bidders are then responsible for protecting } \\
\text { the grass. }\end{array}$ \\
\hline CFI 2 (Baglung) & Once a year & & $\begin{array}{l}\text { The grass is on hilly slops. Each slope is assigned one of three alphabets (A, B, C) according } \\
\text { to the quality of grass it can yield. Each hill is divided into as many plots as there are households. } \\
\text { Each plot is assigned a price and a number. Each household gets a randomly assigned number. } \\
\text { Those unhappy with their assigned plot can exchange it with another household. Those who } \\
\text { want two plots can get a second one from another household on payment. }\end{array}$ \\
\hline
\end{tabular}

Source: author's 2000-2001 survey. 
Table 4

Periodic extraction rules for fodder and firewood.

\begin{tabular}{|c|c|c|c|}
\hline Region & Tree fodder & Grass fodder & Firewood (drywood and greenwood cutting) \\
\hline \multicolumn{4}{|l|}{ Gujarat } \\
\hline Narmada/Bharuch & Not extracted & $\begin{array}{l}\text { Most-69\%-of CFIs allow periodic cutting, } \\
\text { and most have formal procedures for } \\
\text { extraction and distribution. }\end{array}$ & $\begin{array}{l}\text { Extraction is banned by most CFIs. None have formal procedures } \\
\text { for extraction and distribution. }\end{array}$ \\
\hline Panchmahals & Not extracted & $\begin{array}{l}\text { Only } 19 \% \text { of CFIs allow periodic cutting, } \\
\text { but none have formal procedures for } \\
\text { extraction and distribution. }\end{array}$ & $\begin{array}{l}\text { About } 52 \% \text { of CFIs allow periodic collection, but none have formal } \\
\text { procedures for extraction and distribution. }\end{array}$ \\
\hline Sabarkantha & Not extracted & $\begin{array}{l}\text { About } 39 \% \text { of CFIs allow periodic cutting, } \\
\text { but only some have formal procedures for } \\
\text { extraction and distribution. }\end{array}$ & $\begin{array}{l}\text { About } 29 \% \text { allow periodic collection, but very few have formal } \\
\text { procedures for extraction and distribution. }\end{array}$ \\
\hline \multicolumn{4}{|l|}{ Nepal } \\
\hline Gorkha/Dhading & $\begin{array}{l}\text { Most CFIs ban collection. } \\
\text { The } 11 \% \text { that allow periodic } \\
\text { extraction and distribution } \\
\text { have formal procedures. }\end{array}$ & $\begin{array}{l}\text { Only } 17 \% \text { have periodic grass extraction, } \\
\text { and few specify formal procedures for } \\
\text { extraction and distribution. }\end{array}$ & $\begin{array}{l}\text { About } 83 \% \text { organize periodic extraction and distribution, mostly } \\
\text { under formal procedures but infrequently, as part of mandatory } \\
\text { forest pruning/clearing operations. Only some also open the forest } \\
\text { for informal collection. }\end{array}$ \\
\hline Baglung/Parbat & $\begin{array}{l}\text { About } 53 \% \text { of the CFIs formally } \\
\text { organize periodic extraction } \\
\text { and distribution. }\end{array}$ & $\begin{array}{l}\text { Most- } 88 \% \text {-of the CFIs formally organize } \\
\text { periodic extraction and distribution. }\end{array}$ & $\begin{array}{l}\text { About } 97 \% \text { organize formal extraction and distribution, but } \\
\text { infrequently, as part of mandatory forest pruning/clearing } \\
\text { operations. Only some also open the forest for informal collection. }\end{array}$ \\
\hline
\end{tabular}

Source: author's 2000-2001 survey.

\subsection{Aggregation: strictness index}

For the index, the product-wise rules were aggregated as follows:

$S=w_{1} P_{1}+w_{2} P_{2}+\ldots \ldots \ldots \ldots w_{n} P_{n}=\sum_{i=1}^{n} w_{i} P_{i}$

where $S$ is the strictness index, $P_{1}, P_{2}, \ldots \ldots . . P_{n}$ are the $n$ forest products/uses and $w_{1}, w_{2}, \ldots \ldots . w_{n}$ are the weights depending on the degree of strictness of rules for that product/use.

All the forest products are weighted equally, since there was no obvious justification for weighting them differentially. ${ }^{14}$ However, for any given product, the degree of strictness is weighted differentially, as below:

- Full ban $=3$

- Partial ban, and 'given on request' (on personal need or natural disaster $)=2.75$ since these are closer to a full ban than to 'open occasionally'

- 'Open occasionally' $=2.5$ since this is closer to full ban than 'open always' but less close than 'partial ban'; and

- 'Open always' $=1$

The value of $w$ ranges between 1 and $3 .^{15}$ The number of forest uses included in the index is six for Gujarat and seven for Nepal. For Gujarat, the index includes rules for fallen twigs, drywood, timber species for firewood, grass fodder, grazing, and timber poles for house building. For Nepal, the index includes rules for fallen twigs, drywood, tree fodder, grass fodder, timber, leaf litter, and grazing. The strictness index lies between 6 to 18 for Gujarat, and 7 to 21 for Nepal. The percentage of CFIs with given strictness scores for different items are given in Tables 1 and 2 . The observed variations largely relate to firewood and fodder rules. Occasionally other items are also extracted, such as wood for

\footnotetext{
14 For instance, fodder extraction in Nepal can take the form of tree fodder plucking, grass fodder cutting, or grazing. All three provide cattle feed and access can depend on availability and other factors. There is no obvious reason for giving different weights for different types of fodder.

15 Any system of weightage would have an element of ad hocism. Here the logic is that between the two extremes-total ban and open always-lie rules which allow some extraction, but the extent (e.g. opening up the forest for a few days annually or giving for a specified need) deviates only a small degree from a full ban. The weights reflect this relative closeness to a full ban, such as 2.50 and 2.75 which is close to the weight of 3 for a full ban and distant from the weight of 1 for open always. However, using slightly different weights by reducing those for open occasionally by 0.25 points, for instance, does not change the results in terms of the statistical significance of most of the explanatory variables.
}

cremation, or flowers, wild vegetables and berries, but information on these items was lacking for many sites, or not relevant (the forest had none). Hence these products are not included in the index.

\subsection{Hypotheses}

How might the gender composition of rule making bodies impinge on the rules, in particular their extent of strictness? Would women's greater presence in the EC make a difference? We might argue that this would depend on what kinds of rules might be in women's interest. Given their everyday dependence on local forests for firewood and fodder, lenient rules which allow substantial extraction would appear to be more in their interest. However, immediate and long-term interests can vary. Short-term interests may lie in immediate extraction, but long-term interest would lie in deferred and sustainable extraction (in other words framing stricter rules that allow resource regeneration). If the forest is highly degraded, immediate extraction may not even be an option. But as a forest improves, the question of when to start extracting and how much to extract needs to be resolved. As noted earlier, this will be based, at least in part, on negotiation among different parties, especially between villagers and EC members and among the EC members. Hence the EC's gender composition and the intersection of gender and class can prove important. The poorer a woman, the less would be her capacity to defer current consumption and the more would she be interested in lenient rules.

Of course not all aspects that can affect the rules can be captured empirically, or directly. Perceptions about who is most likely to violate the rules is a case in point. There is a general (and often incorrect) perception, for example, that women are more likely to break rules than men: $44 \%$ of CFIs in Nepal perceived women to be the main violators although only $13 \%$ of actual identified violations were by women (Agarwal, forthcoming). Male EC members are thus less willing to open the forest for extracting dry firewood on the argument that women will also take greenwood. There is often a similar perception about the landless. Perception bias cannot be quantified readily, but its potential effects, as subsumed in other variables, are discussed below under monitoring constraints.

My empirical analysis focuses especially on the characteristics of the EC, the CFI, the population and the resource (forest) base, which are all likely to matter by impinging on people's time preferences, monitoring costs and resource constraints; and each of these can have gender and class dimensions. External agents can also influence rule formulation. 


\subsubsection{Time preference}

Unlike many other kinds of rules, those relating to environmental resources deal with the choices we make today for benefits that accrue in the future. Hence rules would reflect time preferences, predicated on the ability or willingness to defer current consumption. ${ }^{16}$ The greater this ability and willingness, the lower the time preference. Gender, age, economic class and caste status-individually and/or interactively-can all affect this.

First, we would expect women's time preference to be much higher than men's, given notable gender differences in the use of and dependence on local forests and commons. In particular, women's primary responsibility for firewood and fodder; their substantial dependence on common pool resources for procuring these items (given their lesser access than men to financial resources and land), and the everyday nature of their dependence, all make it more difficult for women to defer current use for future benefits. When forests are closed it is women who bear the immediate burden of finding alternative sources, especially for fuel and fodder. In contrast, men's much more sporadic use of the forest for timber to make agricultural implements and poles for house building and repairs, and their greater ability to make up for shortfalls through purchase, would make for a lower time preference. However, insofar as women, relative to men, tend to think more about children's needs than personal needs-and there is substantial evidence that they do ${ }^{17}$-they might be more willing to endure the current costs of conserving forests. Hence, although in general we would expect women's presence in the EC to be associated with less strict rules insofar as self-interest prevails, they might make more strict rules if concern for their children's future prevails and the forests need time to recover. The one caveat to this would again be landless women who lack other means for fulfilling even their children's immediate needs. As one woman poignantly asked me: [what should I do] 'when [my] children's stomachs hurt if there is no firewood to cook them a meal'?

Second, we would expect the elderly to have lower time preferences than the young, since the former would be more concerned about leaving a legacy for their children. ${ }^{18}$ Also older people, especially older women living in extended families, tend to have grown up children and daughters-in-law to shoulder the burden of finding alternative sites for fuel and fodder if the forest is closed. In contrast, younger people who face the immediate costs of fuel or fodder shortages would be more inclined toward lenient rules. Hence the greater the EC's average age the stricter would we expect the rules to be.

Third, economic class, especially women's, could influence time preferences. Women from landless households are likely to have a higher time preference than those who have family land as a supplementary source of fuel, fodder, leaf litter, etc. The more land the EC members own, the fewer difficulties they would face from strict closure. ECs with a higher percentage of landless, and especially of female landless members, might thus veer toward more lenient rules and ECs with higher average land ownership might veer toward stricter rules. The effect of inequality in EC landownership (gini coefficient), could go either way, depending on whether the interests of the landpoor or the landed prevail, although no EC member owned

\footnotetext{
${ }^{16}$ There is a substantial economics literature on time preferences, but see especially, Becker and Mulligan (1997).

17 See references in Agarwal (1994) on women's greater concern for children as indicated by their use of economic resources.

${ }^{18}$ Some people, assuming a purely self-interested individual, might well argue the contrary, namely that the elderly will have higher time preferences since they have less time to live. But such an assumption would mean ignoring social norms or social arrangements (e.g. inter-dependent living in joint families in South Asia) that promote other-regarding preferences, or the global evidence on altruistic inter-generational transfers of wealth which require that you consume less today to pass on something to your children (see also, Stark, 1995, and Falk and Stark, 2000).
}

over 4.2 ha in Gujarat or over 2 ha in Nepal (where almost all EC members owned some land).

Fourth, time preferences might differ by caste. Upper-castes tend to be better-off and also place more social restrictions on women's mobility. They are thus likely to depend less on local forests for daily use than the lower castes, and so would suffer less hardship from restrictions on forest use. ECs with more Brahmins, for instance, would tend to veer toward stricter rules. Nepal has a fair degree of caste variation, but in the Gujarat sample tribal communities dominate.

\subsubsection{Monitoring costs}

Monitoring costs-actual or perceived-are another major factor impinging on rules. Both strict forest closure and periodic extraction involve supervision, but in different extent. Forest closure requires continuous long-term monitoring (by patrolling, keeping a guard, etc). Opening up the forest for controlled extraction requires shortterm but complicated supervision to ensure that only the eligible enter and take only what is authorized. Given the monitoring costs of periodic opening, we might expect the CFI rule makers to be somewhat reluctant to make rules which allow extraction.

Both types of monitoring costs would be affected by village and forest characteristics. The more numerous the village households, for instance, the more difficult it would be to oversee periodic extraction, thus creating tendencies toward stricter rules. Villages that have a large landless population might also go for stricter rules, expecting the forest-dependent landless to break rules if the forest is opened. This could arise as much from perceptions about the likelihood of rule violation, as from evidence that the landless break rules more often. Actual and perceived difficulties of monitoring would also be linked to forest size, but the effects could move in either direction. Rules could be stricter in large forests insofar as extractions are more difficult to monitor, or they could be less strict since more can be extracted without harming regeneration. ${ }^{19}$ Both aspects would play out simultaneously. Forest segments (non-contiguous parts) could also affect monitoring costs. A segmented forest is difficult to supervise in a centralized way. In Panchamahals (Gujarat), for instance, villages with more segments tend to protect hamlet-wise, through communities located near a forest patch which keep an informal lookout. These communities need incentives to protect, such as being allowed to extract. This would make for less strict rules. This was tested for Gujarat but not for Nepal, both due to data gaps and because most of Nepal's CFIs protect one segment carved out of the larger forest, rather than a historically inherited forest encroached upon and fragmented over time, as in Gujarat.

Gender can impinge on monitoring in various ways. All-women groups (as in Nepal) compared with 'other' groups (namely, mixedgender groups plus the five all-male groups) are likely to be more constrained in supervising extractions and may therefore opt for stricter rules.

\subsubsection{Resource constraints}

Forest characteristics-its size, condition, age, and segments-can also restrict forest use. Forest size per se would have a mixed effect, as noted above. A large forest reduces the resource constraint so that potentially more biomass can be withdrawn sustainably through less strict rules, but size increases the monitoring constraint which could lead to stricter rules. The forest's age can matter in that younger forests are more vulnerable to damage by people and animals and would encourage stricter rules which bar entry. This can change as the forest ages. Similarly, the larger the 'gapfilled' area (trees planted to

\footnotetext{
19 Total forest size and total village households thus each matter independently, apart from interactively. I therefore chose to keep both variables rather than a standardized forest per household measure. There is also a high correlation between forest size and forest per household ( 0.88 in Gujarat), and substituting the latter for the former did not change the regression results in terms of the variables which were significant.
} 
cover severely degraded patches) or new plantation area, the more restrictions there are likely to be to protect young shoots. In principle this strictness could decline over time, but in practice rules, once made, can prove to be 'sticky.'

A gender dimension is indirectly linked to forest size and condition. In Nepal, all-women groups are systematically allocated smaller (on average half the size), younger, and more degraded forests than other groups. Hence all-women groups tend to have less freedom of extraction than other groups, which could lead them to make stricter rules. The interactive effect of gender and forest size is examined through an interaction term (namely, the product of forest area protected and the relevant gender variable).

Resource constraints can of course be eased somewhat if the community can draw on alternative sources of fuel and fodder, such as their own land or other forests nearby. In Nepal, for instance, people can belong to more than one CFI, and so access other protected forests. This option allows a community to better protect its own by making stricter rules, especially where its own forest is small and degraded, as is typical of all-women groups.

\subsubsection{External influences}

Finally, NGOs, donors, the forest department, and a women's association could all influence the rules as 'external agents,' either directly if CFIs seek their help for framing rules, or indirectly through their influence on EC members. The effect of the forest department vs. villagers and donors (in Nepal), and of the women's association (in both Nepal and Gujarat) are measured directly through dummy variables. A woman's association could support the EC women but it can also oppose them, especially if the class composition of the women's association is different from that of the EC. Typically the Gujarat associations are constituted of somewhat better-off women than those in Nepal. In some Gujarat districts, such as Narmada/ Bharuch, however, almost all the villages have a women's association so this cannot explain rule differences here. Moreover, in Gujarat as a whole, $81 \%$ of CFIs reported that villagers alone decided the rules, so external involvement in rule making is not used as an explanatory variable in the Gujarat analysis, although there could be indirect NGO influence. Some indirect effects of external agents are also captured by the district dummies.

To test the above hypotheses, regressions were run jointly for all districts and also separately for each one, since some of the explanatory variables have district-specific characteristics, such as a large percentage of landless women on the EC or forests of large size, the effects of which can get obscured in the aggregate analysis. In addition, analysis was undertaken individually for selected forest products for which there is sufficient variation in rules to make comparisons relevant.

It needs mention that in the analysis I do not expect potential problems of omitted variable bias or reverse causality in relation to the EC's gender composition, which is our primary explanatory variable. A specific probing of the factors underlying variations in the ECs' gender composition revealed, as noted above, that the factors were largely non-systematic and context-specific, often varying by village. The forest use rules are also highly variable and product-specific. Hence, there is little reason to expect that some omitted variable would systematically affect both EC gender composition and rules in a given direction. Reverse causality, again, is substantially ruled out since rules are made after the EC is formed. In other words, ECs are constituted in time ' $t$ ' and in turn formulate forest use rules in time ' $t+k$.' Subsequent changes in the EC's gender composition are moderate (20\% in Gujarat and 16\% in Nepal), but even in these cases the rules' strictness category has shifted in only three CFIs in Gujarat and four in Nepal. Moreover, I found that in no case was there a change in the EC's gender composition as a conscious response to the potential effect of women's presence on rule formulation. Thus while gender composition can have a bearing on rule changes, the reverse appears unlikely.

\section{Regression results}

The regression results are summarized in Tables 5 and 6 and the variable definitions and descriptive statistics are given in the Appendix Tables A1-A3.

Table 5

Gujarat: factors affecting strictness of rules.

\begin{tabular}{|c|c|c|c|c|}
\hline Dependent variable & Strictness index & & & \\
\hline Statistical method & $\overline{\mathrm{OLS}}$ & & & \\
\hline Region & All districts & Narmada/Bharuch & Panchmahals & Sabarkantha \\
\hline Equation no. & 1 & 2 & 3 & 4 \\
\hline No. of observations & 59 & 16 & 20 & 28 \\
\hline Adjusted $R^{2}$ & 0.0565 & 0.3462 & $0.8236^{* * * *}$ & $0.2647 * *$ \\
\hline Explanatory variables & Coef. & Coef. & Coef. & Coef. \\
\hline GenComp1: dummy (>2 EC women =1) & $0.70(0.346)$ & $5.57 * * *(0.031)$ & $-4.11 * * * *(0.002)$ & $1.73 * *(0.073)$ \\
\hline Women's association: dummy (assoc. exists $=1$ ) & $1.33^{* *}(0.099)$ & & $2.73 * * * *(0.003)$ & $-0.18(0.852)$ \\
\hline \% EC women from landless households & $0.03(0.121)$ & & $-0.07^{* * *}(0.027)$ & \\
\hline$\%$ all EC members from landless households & $-0.06(0.305)$ & $0.09(0.288)$ & $0.21 * * *(0.034)$ & \\
\hline Average age of all EC members ${ }^{a}$ & $-0.01(0.899)$ & & & \\
\hline Gini coefficient for land owned by EC & $-1.97(0.612)$ & $-15.68 * *(0.089)$ & $1.42(0.733)$ & $-6.47(0.189)$ \\
\hline Forest area protected (ha) & $0.00(0.804)$ & $0.04(0.245)$ & $0.004^{*}(0.104)$ & $0.003(0.171)$ \\
\hline Forest segments & $-0.57^{*}(0.105)$ & $0.20(0.801)$ & $-0.24(0.348)$ & $-2.28^{* * * *}(0.050)$ \\
\hline Gapfilled plus plantation area (ha) & $-0.001(0.955)$ & $0.001(0.987)$ & $0.15^{* * *}(0.011)$ & $-0.11^{* * * *}(0.004)$ \\
\hline Total households in village & $0.01^{* * *}(0.041)$ & $0.02 * *(0.053)$ & $0.01 * * * *(0.004)$ & $0.01^{* * *}(0.020)$ \\
\hline$\%$ landless households in village & $0.07 * *(0.085)$ & $-0.04(0.408)$ & $0.10(0.330)$ & $0.20 * * * *(0.008)$ \\
\hline Constant & 12.98 & 10.98 & 11.60 & 15.69 \\
\hline
\end{tabular}

Numbers in parenthesis are $p$-values. Significance: ${ }^{*}$ close to $10 \%, * * 10 \%, * * * 5 \%$, **** $1 \%$.

The Breusch-Pagan test indicated no heteroskedasticity in any of the equations.

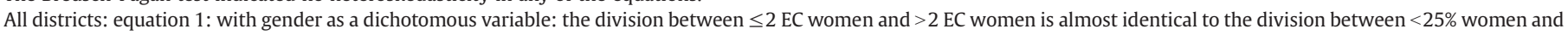
$\geq 25 \%$ women in the EC.

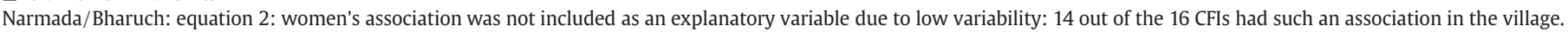
Similarly percent landless EC women was not included since only two CFIs had landless women EC members.

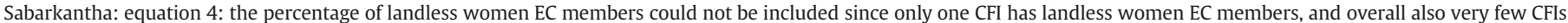
had any landless EC members.

a Average age of the EC was also found insignificant in the district-wise runs, and was not included in the final district-level equations given sample size constraints. 
Table 6

Nepal: factors affecting strictness of rules.

\begin{tabular}{|c|c|c|c|c|c|}
\hline \multirow{2}{*}{$\begin{array}{l}\text { Dependent variable } \\
\text { Statistical method }\end{array}$} & \multicolumn{5}{|l|}{ Strictness index } \\
\hline & \multicolumn{5}{|l|}{$\overline{\mathrm{OLS}}$} \\
\hline Region & All districts & & & Gorkha/Dhading & Baglung/Parbat \\
\hline Equation no. & 1 & 2 & 3 & 4 & 5 \\
\hline No. of observations & 67 & 67 & 67 & 35 & 32 \\
\hline Adjusted $R^{2}$ & $0.3987^{* * * *}$ & $0.4145^{* * * *}$ & $0.3717 * * * *$ & $0.2876^{* *}$ & 0.0079 \\
\hline Explanatory variables & Coef. & Coef. & Coef. & Coef. & Coef. \\
\hline GenComp: dummy (all-women $\mathrm{EC}=1$ ) & $2.49 * * *(0.012)$ & & & $3.44 * * *(0.049)$ & $0.71(0.555)$ \\
\hline GenComp2: \% EC women & & $0.04 * * * *(0.005)$ & $0.02 * * *(0.020)$ & & \\
\hline Women's association: dummy (assoc. exists $=1$ ) & $0.11(0.851)$ & $-0.17(0.785)$ & $-0.40(0.517)$ & $-0.86(0.377)$ & $0.79(0.353)$ \\
\hline Average age of all EC members & $0.18^{* * * *}(0.005)$ & $0.19 * * * *(0.003)$ & $0.23 * * * *(0.001)$ & $0.24 * * *(0.031)$ & $0.04(0.644)$ \\
\hline Average land owned by EC members (ha) & $1.08(0.140)$ & $1.15(0.112)$ & $1.01(0.163)$ & $2.60 * * *(0.045)$ & $-0.18(0.728)$ \\
\hline Gini coefficient for land owned by EC & $6.51 * * *(0.045)$ & $5.41 * *(0.093)$ & & $10.54(0.110)$ & $0.80(0.784)$ \\
\hline$\%$ Brahmins in EC & $0.02 * * *(0.017)$ & $0.02 * * *(0.019)$ & $0.02^{* * *}(0.045)$ & $0.03^{* *}(0.059)$ & $0.01(0.410)$ \\
\hline Member of another CFI: dummy (if member $=1$ ) & $0.89(0.235)$ & $0.79(0.287)$ & $1.30 * *(0.081)$ & $0.80(0.539)$ & $-0.11(0.929)$ \\
\hline Who made forest use rules (no help from $\mathrm{FD}=1$ ) & $0.62(0.365)$ & $0.66(0.319)$ & $0.48(0.481)$ & $1.01(0.304)$ & $-1.20(0.155)$ \\
\hline Forest area protected (ha) & $0.01(0.334)$ & $0.03 * *(0.071)$ & $0.01(0.571)$ & $0.02(0.208)$ & $0.01(0.183)$ \\
\hline Interactive term 1 : forest area with GenComp & $-0.06^{* * *}(0.036)$ & & & $-0.04(0.387)$ & $-0.07^{* *}(0.096)$ \\
\hline Interactive term 2: forest area with GenComp2 & & $-0.001^{* * *}(0.042)$ & & & \\
\hline Forest age: dummy (medium or old $=1$ ) & $-0.26(0.651)$ & $-0.20(0.723)$ & & $-0.93(0.325)$ & $-0.76(0.458)$ \\
\hline No. of toles & $-0.05(0.649)$ & $-0.06(0.569)$ & $-0.04(0.739)$ & $-0.16(0.473)$ & $0.07(0.524)$ \\
\hline District: dummy (Baglung/Parbat = 1) & $2.44^{* * * *}(0.001)$ & $2.52^{* * * *}(0.001)$ & $2.36^{* * * *}(0.001)$ & & \\
\hline Constant & 2.48 & 1.23 & 1.95 & -2.35 & 15.10 \\
\hline
\end{tabular}

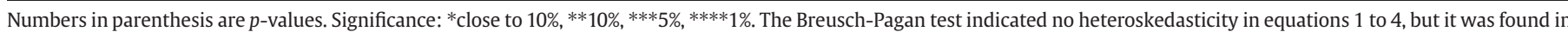
equation 5 . The regression results for this equation are based on robust standard errors.

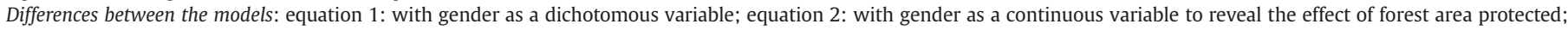
equation 3: omits the interactive term and forest age dummy to reveal the effect of membership in another CFI.

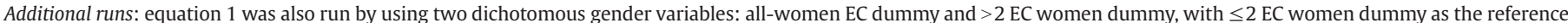

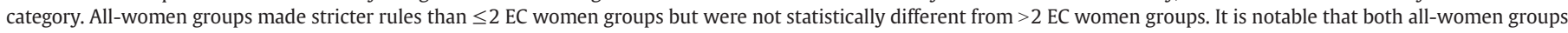
and $>2$ EC women groups received smaller forests than $\leq 2$ EC women groups.

\subsection{Gender variables}

The gender results (which are robust across different specifications) have some expected and some surprising features. As expected, the impact of the EC's gender composition is significant in most equations for both Gujarat and Nepal. For Gujarat, gender is significant for each district-wise run, although not in the all-district equation (Table 5). For Nepal, gender is significant for all districts taken together and for Gorkha/Dhading, although insignificant for Baglung/ Parbat (Table 6).

It is the direction of the relationship, however, that is unexpected. With one exception, CFIs with more EC women consistently make stricter rules, whether we compare CFIs with $>2$ EC women and those with $\leq 2$ EC women for Gujarat, or we compare groups with allwomen ECs with other groups for Nepal. The exception is the Panchmahals fieldsite in Gujarat: here CFIs with $>2$ EC women have significantly less strict rules by the strictness index than CFIs with $\leq 2$ EC women.

The product-wise results for all districts taken together followed a similar pattern (table not given here). In Gujarat, for instance, although gender was only significant for drywood collection, ECs with more than two women made stricter rules. In Nepal, similarly, all-women ECs relative to other ECs tended to make stricter rules for grass collection and grazing. In addition, since Panchmahals was an exception in the aggregate index, I examined product-wise rules for this district separately. Here gender was only significant for grazing, but again the direction of the relationship was toward lenient rulesCFIs with $>2$ EC women veered toward open always as vs. ban or open occasionally (table not given). In other words of the five regionsGorkha/Dhading, Baglung/Parbat, Narmada/Bharuch, Sabarkantha and Panchmahals-women's greater presence is associated with more strict rules in three, neutral in one, and less strict rules in the last, after controlling for other factors.

Why are rules typically stricter in CFIs with more EC women? And why are such CFIs in Panchmahals an exception? The answers appear to lie in a combination of factors. First, in all the sites, except Panchmahals, the vast majority of EC women belong to landed households, and most ECs have no landless members (Table 7). Women here are thus better placed to fulfill their firewood needs (at least in part) from their own land, and so are more able to accept stricter rules than women from landless households. In Panchmahals, on average, $58 \%$ of the female EC members are landless, compared with only $9 \%$ in Narmada/Bharuch, $0.3 \%$ in Sabarkantha and $1.4 \%$ in Nepal as a whole. ${ }^{20}$ Also $60 \%$ of Panchmahals ECs relative to only $12 \%$ of those in Narrmada/Bharuch, $4 \%$ in Sabarkantha, and 10\% in the Nepal fieldsites have any landless EC women (Table 7).

The overall representation of the landless in the Panchmahals ECs is also disproportionately higher than their presence in the village population. This is not the case in the other districts. For instance, on average, only $2 \%$ of Panchmahals village households are landless compared with $14 \%$ of Panchmahals EC members (Table 7). In Narmada/Bharuch, by contrast, although $21 \%$ of village households on average are landless only $10 \%$ of EC members are landless. In Nepal, landlessness among the EC is very low-1.3\% of all EC members are landless in the sample, and only $11 \%$ of the ECs have any landless EC members. The high proportion of landless women among the women EC members in Panchmahals, compared with the other Gujarat fieldsites and with Nepal, coupled with the disproportionately high percentage of landless per se in the Panchmahals ECs (again mainly due to the presence of landless women) relative to their percentage in the village population, would also explain why women's greater presence is associated with less strict rules in Panchmahals.

Women from landless households will understandably veer toward less strict rules because of their greater forest dependence. Also, landless women, if present in sufficient proportions are usually

\footnotetext{
${ }^{20}$ Landlessness here reflects an EC member's household property status and not individual property status.
} 
Table 7

Gujarat and Nepal: average land owned and landlessness among EC members.

\begin{tabular}{|c|c|c|c|c|c|c|c|}
\hline \multirow[t]{2}{*}{ Districts } & \multirow{2}{*}{$\begin{array}{l}\text { Mean \% landless } \\
\text { HHs in village }\end{array}$} & \multicolumn{3}{|c|}{ Mean \% landless EC members } & \multirow{2}{*}{$\begin{array}{l}\% \text { CFIs with over-representation } \\
\text { of landless in } \mathrm{EC}^{\mathrm{a}}\end{array}$} & \multirow{2}{*}{$\begin{array}{l}\% \text { ECs with female } \\
\text { landless members }\end{array}$} & \multirow{2}{*}{$\begin{array}{l}\text { \% ECs with any } \\
\text { landless members }\end{array}$} \\
\hline & & $\overline{\operatorname{Men}^{c}}$ & Women $^{\mathrm{d}}$ & All & & & \\
\hline \multicolumn{8}{|l|}{ Gujarat } \\
\hline Narmada/Bharuch (16) & 20.8 & 10.0 & 9.1 & 10.0 & 18.8 & 12.5 & 43.8 \\
\hline Panchmahals (20) & $2.0^{\mathrm{b}}$ & 1.6 & 57.5 & 13.8 & 60.0 & 60.0 & 60.0 \\
\hline Sabarkantha (28) & $4.0^{\mathrm{b}}$ & 1.2 & 0.3 & 1.2 & 10.7 & 3.6 & 14.3 \\
\hline All districts (64) & 7.5 & 3.6 & 21.3 & 7.4 & 28.1 & 23.4 & 35.9 \\
\hline \multicolumn{8}{|l|}{ Nepal } \\
\hline Gorkha/Dhading (36) & n.a. & 0.0 & 1.1 & 0.7 & n.a. & 8.3 & 8.3 \\
\hline Baglung/Parbat (34) & n.a. & 1.9 & 1.6 & 1.9 & n.a. & 11.8 & 14.7 \\
\hline All districts $(70)$ & n.a. & 1.0 & 1.4 & 1.3 & n.a. & 10.0 & 11.4 \\
\hline
\end{tabular}

Source: author's 2000-01 survey.

Figures in brackets give the number of CFIs.

n.a. = not applicable, since a village is not the forest protecting unit in Nepal; HHs $=$ households; $N=$ number of CFIs.

a Over-representation is computed here for each CFI by subtracting the percent landless households in the EC from the percent landless households in the village. The remaining CFIs either have under-representation or have no landless in the village.

b Not all villages have landless households.

Means calculated by omitting the 3 all-women ECs.

d Means calculated by omitting the 5 all-men ECs.

found to be less inhibited in speaking up for their concerns than landed women, especially where basic survival issues (such as firewood shortages) are involved (Agarwal, 2008). We can thus infer that the presence of landless women in the EC has played a role in moving the rules toward greater leniency. This is further established by the Panchmahals results (Table 5, Eq. no. 3). We find that over and above having more women in the EC the higher the percentage of landless women among them the less strict are the rules, while simply having more landless in the EC (that is, including landless men) makes for stricter rules. Poor men, unlike poor women, are more likely to go along with other men on rules, since firewood is seen as a female concern and poor men speaking up on their wives' behalf can be labeled as 'henpecked.'

Of course women of all households gain if the CFIs allow more firewood and fodder extraction, since the rules apply to all and even the landed own only small plots. But the benefits are especially important for the landless. Women from landed households are less compelled than those from landless households to make a case for lenient rules and battle this out with male EC members. This does suggest that, in particular contexts, what can make a difference is not simply more female presence in decision-making, but a representation of women who have a particularly strong stake in the outcome, such as poor women.

A second explanation, relevant specifically for Nepal, lies in the resource constraint that CFIs with more EC women (especially allwomen groups) face. In particular, the small-sized, more degraded forests that all-women groups received, leaves them less free to make rules that allow periodic extraction. A gender interest in making less strict rules is thus mediated by their resource constraint. The interactive term between gender and forest area also indicates this (Table 6, Eq. no. 1 and 2). While both gender and forest size are positively related to strictness, the coefficient of the interactive term, although rather small, is significant and negative. This suggests that if women had larger and better forests at their command they would tend toward less strict rules. Also, again especially for all-women groups, the monitoring constraint is likely to be high-it is often more difficult for women alone to take time off and organize the kind of careful supervision that is needed for fodder or firewood extraction. In other words, as hypothesized, gender affects rules in a complex way, mediated especially by the economic situation of the EC women (as found in Gujarat), as well as the greater resource and monitoring constraints that all-women groups face (as found in Nepal).

The effect of women's associations also appears to play out along class lines. In Gujarat, the associations tend to be constituted more of women from landed households. This likely underlies why CFIs in villages with women's associations tend to make stricter rules (Table 5, Eq. no. 1 and 3). In fact, in the Panchmahals results, villages with such associations make stricter rules even while ECs with more women veer toward leniency. In Nepal the women's associations are more class-mixed and have a neutral effect.

\subsection{Other (non-gender) explanatory variables}

Apart from the EC's gender (and class) composition and women's associations, some other variables are also striking. First, as hypothesized, age and caste are significant in Nepal. The average age of the EC members is consistently and positively linked with stricter rules in Nepal (although not in Gujarat), both in the alldistrict runs and in the district-wise runs. Older EC members, as noted, bear less of the burden of strict forest closure since they tend to have grownup children, especially daughters-in-law to help, and also frequently say they want to leave a good forest for their children and grandchildren. Indeed the one consistent refrain in interviews with villagers in almost every CFI was that they hoped their children had learnt to love the forest and would continue protecting 'as their parents and grandparents have done.' Also the environmental histories they recounted to us indicate that many elderly villagers, especially in Gujarat, had led the protection efforts, after seeing the effects of degradation at first hand. ${ }^{21}$

Similarly, caste can matter: the Nepal results consistently indicate that ECs with more upper-caste (Brahmin) members have stricter rules. Brahmins tend to use the local forests less than other groups, either because they are more land-endowed or due to stricter social norms for women, or both. Nepal's Hill Brahmins, for example, are much less dependent on firewood than other hill communities ( $\mathrm{GoN}$, 2001). Economic inequality, as measured by the gini coefficient of land owned by EC members, is also found to be linked with stricter rules in Nepal, the exception being the district-level results for Narmada/ Bharuch

Second, again as hypothesized, the variables associated with monitoring difficulties (actual or perceived) significantly affect the strictness of rules in several equations, especially for Gujarat. Rules tend to be stricter the more the village households, the greater the

\footnotetext{
${ }^{21}$ Agarwal (forthcoming); see also Agrawal (2005) on how villagers can become conservationists over time.
} 
percentage of landless villagers, and the larger the forest area. As noted earlier, supervising periodic forest opening is seen to be more difficult with large populations and landlessness, since villagers assume that the needier will steal unauthorized forest products, if allowed to enter the forest for selected extraction. ${ }^{22}$ The link between strictness and village size is consistent across Gujarat and for all the district-wise runs. However, the positive association between forest size and strictness (in some of the Gujarat and Nepal runs) is the net result of two opposing forces: the higher cost of supervised extraction with larger forests pulling toward greater strictness, and more resource availability pulling toward lesser strictness. The monitoring cost wins out here. Another kind of monitoring problem is linked with forest segments. We find in Gujarat, as hypothesized, less strict rules in segmented forests, which are difficult to guard through a centralized system, and communities allow nearby hamlets to extract as an incentive to protect their patch.

Third, forest characteristics matter, although selectively. In Panchmahals, the larger the newly planted area the stricter the rules, since entry can negatively affect new shoots. The opposite is the case in Sabarkantha where plantations are more mature. Forest size, as already discussed, can have divergent effects on monitoring and resource availability. But the resource availability problem (without any monitoring fall out) can be solved to some extent where communities have legitimate access to another local forest, as possible in Nepal. Here we find some limited indication that CFIs whose users are also members in another CFI tend to make stricter rules (Table 6, Eq. no.3). As one women's group interviewed in the Nepal sites in 2000 said:

We bring most of the firewood from the other side-the Mauyeni community forest. We can fetch dry fallen branches all the time. It is a large forest of mahuwa trees. So we can protect our own better.

The Gujarat villagers have no legal access to another forest although they may use one clandestinely. Inter-district differences (the district dummies) were also consistently insignificant in the Gujarat analysis (models not presented in the tables), but significant in Nepal on several counts. The differences between districts in relation to gender, however, are much better captured by the districtlevel equations, discussed above. Fourth, external agents (other than women's associations, which we have already discussed) have an insignificant impact on rule making, although some indirect effects would have been subsumed in the district dummies.

\subsection{Further discussion}

We have examined the factors affecting the rules as formulated around the time formal protection began. Do the rules change over time? In principle, rules need to be reviewed periodically and adjusted to changes in forest condition and in the size of the forestdependent population, or altered if the initial rules are found too strict or too lax. Most CFIs, however, continue with the initial rules, but about 30\% in Gujarat and 16\% in Nepal mention introducing some changes, occasionally in the distribution methods, but sometimes also in strictness. In Gujarat most of the changes relate to allowing fodder cutting or grazing where these were banned before, while changes to allow more firewood extraction are largely confined to Panchmahals, likely due to the influence of landless EC women there, and village women's complaints about firewood

\footnotetext{
22 Based on their 1980s fieldwork in Nepal, Arnold and Campbell (1986) similarly noted that if communities felt they could not easily control an open harvest they preferred to stop collection altogether.
}

shortages. In Nepal also, rule changes toward leniency are largely for fodder and grazing. Notably, of the mixed-gender CFIs which made some rule changes 56\% in Gujarat and 75\% in Nepal are those with more than two EC women. This suggests that women's greater presence on the EC does give them more influence in CFI decisionmaking, although the changes appear to be largely ad hoc and reactive, rather than through a regularized process of discussion and amendment.

\section{Concluding comments}

Within the overall regulation regime of CFIs, forest use rules are marked by considerable diversity and their extent of strictness varies by product, and by the characteristics of the forest, the population served, and the composition of the decision-making bodies. As hypothesized, the group's gender composition makes a significant difference to the rules formulated but the direction of the difference is unexpected. Given the pressures on women, especially for firewood and fodder collection, we expected them to favour extraction today rather than years later, and so push for lenient rules. We found, however, that CFIs with more women made stricter rules, except in Panchmahals where such CFIs made less strict rules. The high presence of landless women among the Panchmahals ECs making more lenient rules, and their low presence elsewhere (in both Gujarat and Nepal), is clearly one factor underlying this difference. Another is the limited freedom that Nepal's all-women groups have for making lenient rules given their smaller and poorer forests. Age is also a mediator. Older EC members, including older women, tend to make stricter rules, likely because of lower time preferences and lower personal costs from strict closure. In other words, the difference women's proportionate strength makes to forest use rules is tempered by their class, age, the product extracted, and the resource constraint that women-dominant ECs face.

How might we expect the structure of rules associated with women's greater presence (stricter in some regions, less so in others) to play out in terms of equity, institutional sustainability and conservation? To begin with, less strict rules would imply more equitable outcomes, since they allow greater extraction of products such as firewood which would benefit women (particularly the poor) in an immediate sense. CFIs in Panchmahals with a high representation of landless EC women which veer toward less strict rules are thus likely to be more equitable than CFIs with a low presence of landless EC women, both in Panchmahals and elsewhere in Gujarat, as well as in Nepal.

We would also expect institutional sustainability to be higher among CFIs with a high proportion of EC women, especially the landless, since by involving those most dependent on the forest the CFIs are more likely to make socially acceptable rules and ensure greater commitment to rule compliance and protection. Overall it would thus help better fulfill the principles identified in institutional analysis as key to building enduring CPR institutions.

The effect on conservation is somewhat more difficult to predict but overall is likely to be positive insofar as the rules are adapted to social and ecological conditions. In the Gujarat sites, where highly forest-dependent tribal communities dominate and landlessness is non-trivial in several parts, and where the protected forests are relatively large and non-timber firewood species are common, the less strict rules made by CFIs with a notable presence of landless EC women appear appropriate socially as well as ecologically. In contrast, the rules made in women's absence can be overly conservative in ecological terms, while being socially inadequate. This inference is also supported by data on biomass regeneration and extraction collected by a set of scholars and practitioners in two Panchmahals villages. These villages, which had less than two women in their ECs, were found 
extracting less than $10 \%$ of the firewood they could extract sustainably, sustainable extraction being defined as $50 \%$ of the annual biomass generated (see Agarwal, 2006 for details). Here women's complaints about firewood shortages were also acute. We might therefore surmise that involving more landless women in rule making, and moving toward leniency in those Gujarat villages which currently have strict rules, could improve conservation by enhancing the social acceptance of rules, while maintaining ecological sustainability.

In Nepal, however, the stricter rules framed by groups with allwomen ECs seem ecologically appropriate, given their smaller and poorer forests, and could also prove to be fairly acceptable socially, since the region has a low incidence of landlessness. Moreover, that the women voluntarily make stricter rules despite any personal hardship (and even when, as with all-women ECs, they control rule making) indicates that their governance practices are informed by a notable concern for conservation. Hence here also the induction of more women in ECs would benefit the forests.
My results, reported in Agarwal (forthcoming), support these propositions and show that ECs with more women are indeed linked with greater forest improvement, both in Panchmahals (and Gujarat more generally) and in Nepal.

\section{Acknowledgements}

I am grateful to Robert Jensen, Paul Seabright, Raghav Gaiha, Manoj Pandey, Vikram Dayal, Bharat Pokharel and the journal's anonymous referees for their valuable comments on the aspects of this paper. I also thank Manoj Pandey and Ram Ashish Yadav for their excellent statistical assistance; my research teams in India and Nepal for their dedicated fieldwork; and AKRSP(I), SARTHI and VIKSAT (all in Gujarat), and FECOFUN AND ICIMOD (in Nepal) for their local support. The data used was collected through a Ford Foundation (Delhi) grant, and I am most grateful to the Foundation for its support. Finally, I thank Gowher Rizvi and the Ash Institute at Harvard University for their hospitality during 2006 when I undertook part of the analysis.

\section{Appendix A}

Table A1

Gujarat: all districts regression variables: definitions and descriptive statistics.

\begin{tabular}{|c|c|c|c|c|c|}
\hline Variables names and definitions & $N$ & Mean & CV & Min & Max \\
\hline \multicolumn{6}{|l|}{ Dependent variables } \\
\hline $\begin{array}{l}\text { Strictness index: sum of six strictness scores (aggregate of scores for twigs collection, drywood cutting, grass fodder cutting, } \\
\text { grazing, cutting timber species for firewood and cutting timber poles for house building). }\end{array}$ & 65 & 13.9 & 0.18 & 9.8 & 17.5 \\
\hline \multicolumn{6}{|l|}{$\begin{array}{l}\text { Weights: open always }=1 \text {; open occasionally }=2.5 \text {; partial ban, or given on request for special need or on natural disaster }=2.75 \text {; } \\
\text { full ban }=3 \text {. (all products carry the same weight structure. Range of values: } 6 \text { to } 18 \text { ) }\end{array}$} \\
\hline \multicolumn{6}{|l|}{ See text for the method used to compute the index. } \\
\hline \multicolumn{6}{|l|}{ Explanatory variables } \\
\hline GenComp1: dummy: If EC has $>2$ women $=1$; if $\leq 2$ women $=0$ & 65 & 34 & n.a. & 0 & 1 \\
\hline Women's association in village: dummy: If association exists $=1$; If not $=0$ & 65 & 44 & n.a. & 0 & 1 \\
\hline \% EC women from landless hhs & 59 & 21.3 & 1.86 & 0 & 100 \\
\hline$\%$ all EC members from landless hhs & 64 & 7.4 & 1.65 & 0 & 55.6 \\
\hline Average age of EC members & 64 & 43.6 & 0.14 & 28.1 & 55.6 \\
\hline Gini coefficient for land owned by EC & 64 & 0.3 & 0.37 & 0.1 & 0.7 \\
\hline Forest area protected in $2000-2001$ (ha) & 65 & 164.9 & 1.3 & 15 & 1536.8 \\
\hline Forest segments: no. of non-contiguous parts of protected forest & 65 & 1.9 & 0.61 & 1 & 6 \\
\hline Gapfilled plus plantation area (ha) & 65 & 15.6 & 1.65 & 0 & 120 \\
\hline Total households in village & 65 & 183.4 & 0.70 & 36 & 758 \\
\hline$\%$ landless households in village & 65 & 7.5 & 1.60 & 0 & 40.6 \\
\hline
\end{tabular}

Notes: for the dummy variables the means give the number of positive values. $\mathrm{CV}=$ coefficient of variation.

Table A2

Gujarat: district-wise regression variables: definitions and descriptive statistics.

\begin{tabular}{|c|c|c|c|c|c|c|c|c|c|c|c|c|c|c|c|}
\hline \multirow[t]{2}{*}{ Variables names and definitions } & \multicolumn{5}{|c|}{ Narmada/Bharuch } & \multicolumn{5}{|c|}{ Panchmahals } & \multicolumn{5}{|c|}{ Sabarkantha } \\
\hline & $\bar{N}$ & Mean & $\mathrm{CV}$ & Min & $\operatorname{Max}$ & $N$ & Mean & $\mathrm{CV}$ & Min & $\operatorname{Max}$ & $N$ & Mean & $\mathrm{CV}$ & Min & Max \\
\hline \multicolumn{16}{|l|}{ Dependent variables } \\
\hline Strictness index & 16 & 14.7 & 0.16 & 10 & 17.5 & 21 & 13.2 & 0.21 & 9.8 & 17 & 28 & 14.0 & 0.17 & 10 & 17.5 \\
\hline \multicolumn{16}{|l|}{ Explanatory variables } \\
\hline GenComp1: dummy: If EC has $>2$ women $=1$; EC has $\leq 2$ women $=0$ & 16 & 8 & n.a. & 0 & 1 & 21 & 10 & n.a. & 0 & 1 & 28 & 16 & n.a. & 0 & 1 \\
\hline $\begin{array}{l}\text { Women's association in village: dummy: } \\
\text { If association exists }=1 \text {; If not }=0\end{array}$ & 16 & 14 & n.a. & 0 & 1 & 21 & 12 & n.a. & 0 & 1 & 28 & 18 & n.a. & 0 & 1 \\
\hline \% EC women from landless households & 11 & 9.1 & 2.37 & 0 & 66.7 & 20 & 57.5 & 0.86 & 0 & 100 & 28 & 0.3 & 5.29 & 0 & 9.1 \\
\hline \% all EC members from landless households & 16 & 10.0 & 1.59 & 0 & 55.6 & 20 & 13.8 & 0.95 & 0 & 36.4 & 28 & 1.2 & 2.50 & 0 & 9.1 \\
\hline Gini coefficient for land owned by EC & 16 & 0.4 & 0.39 & 0.1 & 0.7 & 20 & 0.3 & 0.35 & 0.1 & 0.5 & 28 & 0.3 & 0.32 & 0.1 & 0.5 \\
\hline Forest area protected in $2000-2001$ (ha) & 16 & 57.9 & 0.65 & 20 & 120 & 21 & 224.6 & 0.72 & 15.3 & 546 & 28 & 181.4 & 1.54 & 15 & 1536.8 \\
\hline Forest segments: no. of non-contiguous parts of protected forest & 16 & 1.8 & 0.46 & 1 & 4 & 21 & 2.7 & 0.52 & 1 & 6 & 28 & 1.3 & 0.46 & 1 & 3 \\
\hline Gapfilled plus plantation area (ha) & 16 & 46.9 & 0.67 & 20 & 120 & 21 & 5.1 & 1.79 & 0 & 25 & 28 & 5.5 & 2.52 & 0 & 50 \\
\hline Total households in village & 16 & 168.7 & 0.57 & 51 & 353 & 21 & 184.3 & 0.82 & 55 & 758 & 28 & 191 & 0.69 & 36 & 654 \\
\hline \% landless households in village & 16 & 20.8 & 0.67 & 2.4 & 40.6 & 21 & 2.0 & 1.86 & 0 & 12.4 & 28 & 4.0 & 2.22 & 0 & 33.9 \\
\hline
\end{tabular}

Notes: for the dummy variables the means give the number of positive values. $\mathrm{CV}=$ coefficient of variation. 
Table A3

Nepal: all districts and district-wise regression variables: definitions and descriptive statistics.

\begin{tabular}{|c|c|c|c|c|c|c|c|c|c|c|c|c|c|c|c|}
\hline \multirow[t]{2}{*}{ Variable names and definitions } & \multicolumn{5}{|c|}{ All districts } & \multicolumn{5}{|c|}{ Gorkha/Dhading } & \multicolumn{5}{|c|}{ Baglung/Parbat } \\
\hline & $\mathrm{N}$ & Mean & $\mathrm{CV}$ & Min & Max & $\mathrm{N}$ & Mean & $\mathrm{CV}$ & Min & Max & $\mathrm{N}$ & Mean & $\mathrm{CV}$ & Min & Max \\
\hline \multicolumn{16}{|l|}{ Dependent variable } \\
\hline Strictness index: definition same as for Gujarat & 70 & 16.4 & 0.16 & 11.8 & 20 & 36 & 15.0 & 0.18 & 11.8 & 20 & 34 & 17.8 & 0.09 & 12.8 & 20 \\
\hline \multicolumn{16}{|l|}{ Explanatory variables } \\
\hline GenComp: dummy: all-women $\mathrm{EC}=1$; Other $\mathrm{ECs}=0$ & 70 & 27 & n.a. & 0 & 1 & 36 & 16 & n.a. & 0 & 1 & 34 & 11 & n.a. & 0 & 1 \\
\hline GenComp2: \% EC women & 70 & 55.1 & 0.69 & 0 & 100 & 36 & 57.8 & 0.7 & 0 & 100 & 34 & 52.3 & 0.69 & 0 & 100 \\
\hline Women's association: dummy. Active association exists $=1$; If not $=0$ & 70 & 42 & n.a. & 0 & 1 & 36 & 21 & n.a. & 0 & 1 & 34 & 21 & n.a. & 0 & 1 \\
\hline Average age of all EC members in $2000-2001$ & 70 & 41.5 & 0.12 & 30.4 & 54.5 & 36 & 39.5 & 0.11 & 30.4 & 49.3 & 34 & 43.6 & 0.12 & 35.8 & 54.5 \\
\hline Average land owned by EC members (ha) & 67 & 0.8 & 0.52 & 0.2 & 2.0 & 35 & 1.0 & 0.41 & 0.4 & 2.0 & 32 & 0.6 & 0.61 & 0.2 & 2.0 \\
\hline Gini coefficient for land owned by EC & 67 & 0.3 & 0.3 & 0.1 & 0.5 & 35 & 0.3 & 0.3 & 0.1 & 0.4 & 32 & 0.3 & 0.3 & 0.1 & 0.5 \\
\hline \% Brahmins in EC & 70 & 48.6 & 0.77 & 0 & 100 & 36 & 43.2 & 0.80 & 0 & 100 & 34 & 54.3 & 0.74 & 0 & 100 \\
\hline Member of another CFI: dummy. If member $=1$; if not $=0$ & 70 & 53 & n.a. & 0 & 1 & 36 & 27 & n.a. & 0 & 1 & 34 & 26 & n.a. & 0 & 1 \\
\hline $\begin{array}{l}\text { Who made forest use rules: dummy: rules made without FD help }=1 \text {; } \\
\text { if made with FD help }=0\end{array}$ & 70 & 25 & n.a. & 0 & 1 & 36 & 20 & n.a. & 0 & 1 & 34 & 5 & n.a. & 0 & 1 \\
\hline Forest area protected in $2000-2001$ (ha) & 70 & 33.6 & 0.89 & 3.9 & 160 & 36 & 33.1 & 1.00 & 3.9 & 160 & 34 & 34.1 & 0.78 & 4.9 & 105.2 \\
\hline Interactive term 1: forest area with GenComp & 70 & 8.0 & 1.89 & 0 & 75.2 & 36 & 8.4 & 1.83 & 0 & 75.2 & 34 & 7.6 & 2.0 & 0 & 57 \\
\hline Interactive term 2: forest area with GenComp2 & 70 & 1448.4 & 1.0 & 0 & 7525 & 36 & 1393.2 & 1.06 & 0 & 7525 & 34 & 1506.7 & 0.98 & 0 & 5700 \\
\hline Forest age: dummy: If medium or old $=1$; If young $=0$ & 70 & 31 & n.a. & 0 & 1 & 36 & 18 & n.a. & 0 & 1 & 34 & 13 & n.a. & 0 & 1 \\
\hline No. of toles & 70 & 5.2 & 0.47 & 1 & 13 & 36 & 5.1 & 0.43 & 2 & 11 & 34 & 5.2 & 0.52 & 1 & 13 \\
\hline District: dummy: Baglung/Parbat $=1 ;$ Gorkha $/$ Dhading $=0$ & 70 & 34 & n.a. & 0 & 1 & n.a. & & & & & n.a. & & & & \\
\hline
\end{tabular}

Notes: for the dummy variables the means give the number of positive values. $\mathrm{CV}=$ coefficient of variation.

\section{References}

Agarwal, B., 1994. A Field of One's Own: Gender and Land Rights in South Asia. Cambridge University Press, Cambridge.

Agarwal, B., 2001. Participatory exclusions, community forestry and gender: an analysis and conceptual framework. World Development 29 (10), 1623-1648.

Agarwal, B., 2006. Gender inequality, cooperation and environmental sustainability. In: Baland, J.-M., Bowles, S., Bardhan, P. (Eds.), Inequality, Cooperation, and Environmental Sustainability. Princeton University Press, Princeton.

Agarwal, B., 2008. Does women's proportional strength affect their participation? Governing local forests in South Asia. Paper Presented at the IAFFE Annual Conference, Turin.

Agarwal, B. forthcoming. Gender and Environmental Governance. Oxford: Oxford University Press.

Agrawal, A., 1997. Rules, rule making and rule breaking: examining the fit between rule systems and resource use. In: Ostrom, E., Gardner, R., Walker, J. (Eds.), Rules, Games and Common-Pool Resources. University of Michigan Press, Ann Arbor, pp. 267-282.

Agrawal, A., 2005. Environmentality: Technologies of Government and the Making of Subjects. Duke University Press, Durham.

Arnold, J.E.M., Campbell, J.G., 1986. Collective management of hill forests in Nepal. In: Proceedings of the conference on common property resource management. National Research Council. National Academy Press, Washington, DC, pp. 425-454.

Bahuguna, V.K., 2004. Root to canopy: an overview. In: Bahuguna, V.K., Mitra, K. Capistrano, D., Saigal, S. (Eds.), Root to Canopy. Commonwealth Forestry Association and Winrock International, New Delhi, pp. 15-24.

Baland, J.M., Platteau, J.P., 1996. Halting Degradation of Natural Resources: Is There a Role for Rural Communities? Clarendon Press, Oxford.

Bardhan, P. 2006. Inequality and the Governance of Water Resources in Mexico and South India. In Baland, Bowes and Bardhan op cit.

Becker, G., Mulligan, C., 1997. The endogenous determination of time preference. Quarterly Journal of Economics 112, 729-758.

Berkman, M., O'Connor, R., 1993. Do women legislators matter? Female legislators and state abortion policy. American Politics Quarterly 21 (1), 102-124.

Bhattacharya, N., 1992. Colonial state and agrarian society. In: Stein, B. (Ed.), The Making of Agrarian Policy in British India 1770-1900. Oxford University Press, Delhi.

Britt, C., 1993. Out of the Wood? Local Institutions and Community Forest Management in Two Central Himalayan Villages. Cornell University, Ithaca. draft monograph.

Carroll, S.J., 2001. Representing women: women state legislators as agents of policyrelated change. In: Carroll, S.J. (Ed.), The Impact of Women in Public Office. Indiana University Press, Indianapolis.

Chattopadhyay, R., Duflo, E., 2004. Women as policy makers: evidence from an Indiawide randomized policy experiment. Econometrica 72 (5), 1409-1444.

CPFD, 2000. FUG database. Community and Private Forestry Division, Dept. of Forests, Government of Nepal, Kathmandu.

Darcy, R., Welch, S., Clark, J., 1994. Women, Elections and Representation. University of Nebraska Press, London.

Falk, I., Stark, O., 2001. Dynasties and destiny: On the roles of altruism and impatience in the evolution of consumption and bequests. Economica 68 (272), 505-518.

Gandhi, N., Shah, N., 1991. The Issues at Stake: Theory and Practice in the Contemporary Women's Movement in India. Kali for Women, Delhi.
GoN, 2001. Census of Nepal 2001. National Planning Commission, Government of Nepal, Central Bureau of Statistics, Kathmandu.

High-Pippert, A., Comer, J., 1998. Female empowerment: the influence of women representing women. Women and Politics 19 (4), 53-66.

Hobley, M., 1996. Participatory Forestry: The Process of Change in India and Nepal. Overseas Development Institute, London.

Mckean, M.A., 1986. Management of traditional common lands (Iriaichi) in Japan. In: Bromley, D.W. (Ed.), Making the Commons Work: Theory, Practice and Policy Institute for Contemporary Studies Press, San Francisco.

Norris, P., Lovenduski, J., 1995. Political Recruitment: Gender, Race and Class in the British Parliament. Cambridge University Press, Cambridge.

Ojha, H.R., Timsina, N.P., 2008. Community-based forest management programmes in Nepal: lessons and policy implications. In: Ojha, H.R., Timsina, N.P., Kumar, C., Banjade, M.R. (Eds.), Communities Forests and Governance. Adroit Publishers, New Delhi.

Ostrom, E., 1990. Governing the Commons. Cambridge University Press, Cambridge.

Ostrom, E., Gardner, R., Walker, J., 1997. Rules, Games and Common-Pool Resources. University of Michigan Press, Ann Arbor.

Poffenberger, M., McGean, B. (Eds.), 1996. Village Voices, Forest Choices: Joint Forest Management in India. Oxford University Press, Delhi.

Saint-Germain, M.A., 1989. Does their difference make a difference? The impact of women on public policy in the Arizona legislature. Social Science Quarterly 70 (4), 956-968.

Sarin, M., 1998. Who is Gaining? Who is Losing? Gender and Equality Concerns in Joint Forest Management. Society for Promotion of Wastelands Development, New Delhi.

Sivaramakrishnan, K., 1999. Modern Forests: State Making and Environmental Change in Colonial Eastern India. Stanford University Press, Stanford.

Springate-Baginski, O., Blaikie, P. (Eds.), 2007. Forests, People and Power: The Political Ecology of Reform in South Asia. Earthscan, London.

Stark, O., 1995. Altruism and Beyond: An Economic Analysis of Transfers and Exchanges within Families and Groups. Cambridge: Cambridge University Press.

Sundar, N., Jeffreys, R., Thin, N., 2001. Branching out: Joint Forest Management in India. Delhi: Oxford University Press.

Swers, M., 2001. Understanding the policy impact of electing women: evidence from research on congress and state legislatures. Political Science and Politics 34 (2) 217-220.

Thomas, S., 1994. How Women Legislate. Oxford University Press, Oxford.

Thomas, S., Welch, S., 2001. The impact of women in state legislatures: numerical and organizational strength. In: Carroll, S.J. (Ed.), The Impact of Women in Public Office. Indiana University Press, Indianapolis.

Vallance, E., 1988. Do women make a difference? The impact of women MEPs on community equality policy. In: Buckley, M., Andersen, M. (Eds.), Women, Equality and Europe. Macmillan Press, Basingstoke.

Vijaylakshmi, V. 2004. Gender, Accountability and Political Representation in Local Government. Mimeo, Institute for Social and Economic Change, Bangalore.

Wade, R., 1988. Village Republics: Economic Conditions for Collective Action in South India. Cambridge University Press, Cambridge.

Wängnerud, L., 2000. Testing the politics of presence: women's representation in the Swedish Riksdag. Scandinavian Political Studies 23 (1), 67-91. 